DOI: doi.org/10.21009/IJLECR.042.21

Received: 5 June 2018

Revised: 10 June 2018

Accepted: 14 August 2018

Published: 31 December 2018

\title{
THE USE OF ENGLISH INTRODUCTION LANGUAGE IN LEARNING IN MONTESSORI PRESCHOOL INDONESIA
}

\author{
Retno Widiyanti $^{1, \mathrm{a})}$, Yumna Rasyid ${ }^{1, \mathrm{~b})}$, Darmahusni ${ }^{1, \mathrm{c})}$ \\ Language Education Department, State University of Jakarta \\ M Building, Komplek Universitas Negeri Jakarta, Jalan Rawamangun Muka RT. 11/RW. 14, \\ Rawamangun, East Jakarta. Postal Code: 13220, Jakarta, Indonesia ${ }^{1)}$ \\ redthan2012@gmail.com ${ }^{\text {a) }}$,yumna.rasyid@unj.ac.id ${ }^{\text {b) }}$,darmahusni@unj.ac.id ${ }^{\text {c) }}$
}

\begin{abstract}
The use of English introduction language in learning has been found in educational institutions. Although this is very contrary to the law of kemendikbud that Indonesian must be used as the language of instruction in national education, but now it has developed rapidly schools that use English as the medium of instruction in the learning process, even starting from the level of preschool. This phenomenon occurs in the Preschool Indonesia is Montessori Preschool Indonesia where the school includes public schools. This school is a school that uses the English language of instruction, located in the sub-district of Matraman Jakarta Timur among other schools. Preschool Indonesia Montessori was established in 2005. Montessori Indonesia's preschool already uses English as the language of instruction in its early learning. Since its inception this school has produced graduates of students who are independent and confident in communicating using English. In addition, Montessori's Indonesian preschool uses Montessori's method of learning. This is what distinguishes with the existing preschool.
\end{abstract}

Keywords: Introduction language, learning, Montessori Method.

In this globalization era, the world of education has evolved and changed in the use of language systems, where often the education institutions use foreign languages as the language introduction in teaching and learning activities. Where it is now rapidly growing schools that use English as the medium of instruction in the learning process, even started from preschool.

According to the Law on Kemendikbud No 24/2009 on article 29 paragraph (1) which reads "Indonesian must be used as the language introduction in national education". But in reality, there are still many national schools that use English as the language introduction in teaching and learning. And this happens at the lowest level of education, the kindergarten.

The writer made this phenomenon as the focus of research and this occurred in Montessori Preschool Indonesia, namely Indonesia Montessori preschool where the school includes public schools. This school is a school that uses English languageintroduction in the learning, which is located in East Jakarta Matraman Sub-district area among other schools.Indonesia Montessori preschool is established since 2005, which at the beginning of its foundation is Tebet area, South Jakarta.

In addition, Indonesian Montessori preschool uses Montessori method of learning. Indonesia Montessori Preschool has been using English as the introduction in learning since its inception. Montessori argues that in the early years a child has what is called a "Sensitive Period". During this

time the child in particular receives certain stimuli. Learning English at an early age, especially preschool usually tend to succeed because at this time a child will experience rapid growth.In the child's brain is like a sponge that can be absorbing easily, as Montessori termed "The Absorbent Mind".

English learning materials for early childhood should be as attractive as possible. It should we adjust the level of their development. The scopes of materials we can give to early childhood include: names of colours, animal, numbers, family, part of the body, and etc. Indonesia Montessori uses Montessori Method 
for learning. In the Montessori classroom, materials given to children are not merely academic, but also pratical life material, which is usually combined with motor exercises and the child's sense of sharpness from simple things in everyday life, such as shining shoes, cleaning tables, or carry water from the sink and pour it into a bucket, utilized by Montessori education to optimize the motor coordination of the child and the sharpness of the senses.

Indonesia Montessori preschool implements a small classroom of learning with a ratio of 8 students with 1 teacher, in which each class contains colorful classroom embellishments and attracts students to support the introduction of English vocabulary, such as colors, days name, shapes, alphabets, numbers , and others, so that teachers more focused on the development of learners.

The role of teachers also has an important role in learning that uses English as the medium of instruction.Indonesia Montessori preschool has teachers who are fluent in English and 'Montessori' skill.Another thing that distinguishes the Montessori class from the conventional class is there's no a teacher desk that is usually the center of the conventional class. This is because, in the Montessori class, stimulation for learning is expected to come from the classroom as a whole. In addition, storage shelves Montessori class generally low so easily accessible by children and table-chair is not permanently embedded on the floor, so the arrangements can adjust to various activities held. Montessori classes generally also accommodate children to sit on the floor by providing classroom mats.

\section{METHOD}

This present research was carried out by a case study at Indonesia Montessori preschool. Moreover, it is conducted by kindergarten 1 class. The students were 3 students. This researchmethod describes the use of English introduction language in IndonesiaMontessori practice in classroom or out of classroom.

The techniques and procedures used in data collection include (1) observation, (2) in depth interview, (3) document study. In the data collection, the writer assisted another tool in addition in the form of tape recorder to record the phenomenon as a whole, interview and photos as an expansion material if necessary.

\section{RESULTS AND DISCUSSION}

This current research was to discover the use of English introduction language in learning in Indonesia Montessori preschool. After collecting and analyzing data, the research results are displayed based on the research questions.

1. Outdoor classroom activity

\section{a. Greeting}

Based on field findings it is found that the use of English language introduction is not only used in the classroom or during the learning process.It is seen when the Montessori Indonesian preschool students enter the school building, the teachers welcome the students with the words "hi, good morning!" And automatically reply by replying "good morning, miss!".Basically children do not usually have a problem with "confusing language" regardless of context in the use of those languages(Brown 2007:77).

\section{b. Circle time}

Before entering each class, Indonesia Montessori student start from playgroup class to kindergarten 2 sit together in one place (hall) and make a circle, everyday. They have to do this morning routine for about 15 minutes i.e. circle time or sing together and this activity is kind of refreshment or refresh before entering the class. The contents of circle time activities besides singing together, they must complete the weather chart, day, date, month and year. This activity is led by one teacher. The songs that accompany the theme adjusted with each month. In addition, the teacher who leads the activities should also explain some of the vocabulary found on the theme board.

After explaining, the teacher repeats by pointing to one of the students to show a picture of one of the vocabularies described earlier.This is in accordance with Tomlinson said that the teaching materials are used to facilitate language learning, may be to the language itself, images, sound, movement, performances, recordings, CD-ROM, DVD or the Internet(Tomlinson, 2003:2). The students will not feel bored because theyhavefun learning. 


\section{c. Line up session}

After they passed "circle time" session, each teacher calls and instructs the students to line up and prepare for entry into their respective classes. Such as, the following word, "Ok, K 1 class. Please, stand up and make a line. Before you go to your class, let's wash your hand, first!". Montessori said at the preschool age, it is important for adults to converse with children during this period, it will enrich their language continually and give them every opportunity to learn new words (Britton, 2017:18)

2. Indoor classroom activity

a. Before the learning session started

The class teacher performs the students attendance list, that is by calling the students name one by one and the student replied by raising the right hand while replying "present, Ms". After performing the attendance list, the teacher leads the prayer before learning "Ok class, before we start our class today, let us pray first". Afterward, the teacher leads the prayer before learning "Ok class, before we start our class today, let us pray first". Around at 21 months, children use few word phrases

Children easily learn to use all forms of nouns, suffixes, prefixes and varied verbs at the end of the second year of life. Explosive events and eruptions in the strength of his expression continued after two years. Children continue to use sentences simple and complex. The children continue to many new words and refine his sentence formation until the age of 6 years (Britton, 2017: 19).

b. At the time of learning activities

At the time of learning Bahasa Indonesia and religion, the language introduction that is used is Bahasa.Meanwhile at the time of learning English, math, culture and apparatus, the language introduction that is used is English. That is why we have to provide activities in a way that suits their world of play (Nurhadi, 2018).

Each student will get a turn to learn by using Montessori materials. The Montessori Method is known for its structured and sequential methods. "The children who is given the freedom to do his activities, must find something in his environment that is organized in direct relation to the selforganizing within himself that develops itself under natural law" (Jaipaul and James, 2006 : 14).

In other words, the external setting of the environment must imitate and enhance the internal sequence that occurs within the child, so it makes sense that the rhythm and class routine should be predictable, the learning material must be arranged in a logical way, and the delivery of the lesson as a guideline must be precise and concise. This precise structure is manifested in many forms of classes in Montessori, from the daily routine of activities, to finding a material in the expected location, to the symmetry of carefully crafted learning material, and the predictability of the basic rules or limitations governing the behavior of all children.(Jaipaul and James, 2006 : 14).

In language area, the students learn the alphabet by using phonic (the sound of alphabet).The next step, after they have memorized the phonics sound, the teacher will introduce the "pink scheme". The pink scheme is the first stage in word building exercise. The student learn to spell the words consist of three phonics sound.Such as, bat, pin, sun, peg, and hot. If the student have already grasp this stage, the teacher will give the next stage that is "blue scheme" and last stage is "green scheme".

In math area, the student will learn the concept of the number by using Montessori material such as, golden beads, card and counter, spindle box and seguin board. Not only that, they also get the way how to write the number.

In culture area, the student will learn many things. In culture area, there is science, geography and cultural. For science, the student will learn a part of animal body, a part of tree, a part of flower and etc. In geography area, the student will learn the world map and globe. The student will learn the continents of the world.

\section{CONCLUSION}

Based on the research above, the use of English language introduction in Montessori Indonesia preschool that is occurred in Indonesia Montessori which located in East Jakarta is very effective. Even though the students of Indonesia Montessori preschool learn English, they also could read the sentence in Bahasa Indonesia easily. The students will not experience "confused language" when they in bilingual 
system. This happens because of the participation of the teacher. As the facilitator, the teacher should be sort out when they have to speak in English or in Bahasa Indonesia. Montessori Method is appropriate for preschool age. By using this method, it develops the next generation that is ready for the future or the next stage.

This research is recommended for teaching in preschool; there should be no worries if the preschool use bilingual system, the first language that is Bahasa Indonesia will be lost.

\section{REFERENCES}

Brown, H. Douglas, PrinsipPembelajaran dan Pengajaran Bahasa (terjemahan) California : Pearson Education, Inc., 2007

Britton Lesley, Montessori Play and Learn (ed terjemahan),Yogyakarta, PT BentangPustaka, 2017

Carter, Ronald and David Nunan. The Cambridge Guide to Teaching English to Speakers of Other Language. Cambridge University Press, 2001

Creswell, John. Educational Reasearch: Planning, Conducting, and Evaluating Quantitative and Qualitative Research, Third Edition. Upper Saddle River, New Jersey: Pearson Merrill prentice Hall, 2008.

D.Nunan,.Practical English Language Teaching. New York: McGraw-Hill, 2003

Dodge, Diane Trister and Laura J. Coker. The Creative Curriculum for Early Childhood Washington: Teaching Strategies, Inc, 2001

Djamarah, Syaiful B. Guru dan AnakDidikdalamInteraksiEdukatif. Jakarta: RinekaCipta, 2000.

E.James Johnson and Jaipaul ., Pendidikan AnakUsia Dini: DalamBerbagaiPendekatan, Ed ke-8, Pearson Prentice Hall, 2006

Freeman,D. L. Techniques and Principles in Language Teaching. Oxford: Oxford University Press, 2009

Hainstock, Elizabeth G. Teaching Montessori in the Home Pre-School Years 2nd Ed. New York: Elizabeth G. Hainstock, 1997.

Krashen S. Principles and Practice in Second Language Acquisition. Oxford: Pergamon, 1982.

Moleong, Lexy J. MetodologiPenelitianKualitatif( Edisirevisi, Bandung. PT RosdaKarya, 2011.

Muhajir, Neong. MetodologiPenelitianKualitatif .Yogyakarta: Rake Sarasin, 2000.

Pinter, Annamria. Teaching Young Language Learners .Oxford University Press, 2006

Sugiyono, MemahamiPenelitianKualitatif. Cet IV, Bandung: CV. Alfabeta, 2011. 2012 , MetodePenelitian Pendidikan PendekatanKuantitatif, Kualitatif, dan R\&D Bandung: Alfabeta,

Rahardjo, Mudjia, StudiKasusdalamPenelitianKualitattif: Konsep dan Prosedurnya..http://repository.uinmalang.ac.id/1104/1/Studi-kasus-dalam-penelitian-kualitatif.pdf

Tarigan, H. G. PengajaranKedwibahasaan. Bandung: PenerbitAngkasa, 2009

Tomlinson, Brian. Developing Materials for Language Teaching. London: Continuum, 2003

Widdowson, H.G. Teaching Language as Communication. Oxford: Oxford University Press, 1978.

Hajek, John. School of Languages and Linguistics, The University of Melbourne, 2014

Lesley Britton, Montessori Play and Learn (ed terjemahan), (Yogyakarta, PT BentangPustaka, 2017 